Vol. 23, No. 1 (2013) 1-7

http://dx.doi.org/10.6111/JKCGCT.2013.23.1.001

\title{
Development and application of the magnetic field device for single crystal growth
}

\author{
Shin Ae $\mathrm{Kim}^{\dagger}$, Sang-Jin Cho, Elena Magay and Sun-Young Ryu \\ Neutron Science Division, Korea Atomic Energy Research Institute, Daejeon 305-353, Korea
}

(Received November 29, 2012)

(Revised January 30, 2013)

(Accepted February 8, 2013)

\begin{abstract}
The three-dimensional structure of the proteins, including the location of the hydrogen atoms can be analyzed by using neutron diffraction. In order to grow single crystals for neutron diffraction experiments, we developed a simple magnetic field device with the commercial magnets and succeeded in growing hen egg-white lysozyme single crystals of more than $1 \mathrm{~mm}^{3}$ in volume using this device. The crystals grown with a magnetic field were larger and had perfect transparency, whereas the crystals grown without a magnetic field had micro-cracks. The result of the X-ray measurement showed a good resolution and small mosaicity for the crystals grown in the presence of a magnetic field.
\end{abstract}

Key words Magnetic field device, Single crystal growth, Neutron diffraction

\section{자기장 단결정 성장장치의 개발과 적용}

\section{김신애 ${ }^{\dagger}$, 조상진, 엘레나 마가이, 류선영}

한국원자력연구원 중성자과학연구부, 대전, 305-353

(2012년 12월 29일 접수)

(2013년 1월 30일 심사완료)

(2013년 2월 8일 게재확정)

요 약 중성자회절을 이용하여 단백질 내의 수소원자 위치를 포함한 3차원 상세구조를 분석할 수 있으므로, 중성자 회 절용 단백질 단결정을 성장시키기 위해 상용자석을 이용한 자기장 단결정 성장장치를 개발하였다. 이 장치를 이용하여 중 성자 회절실험에 필요한 $1 \mathrm{~mm}^{3}$ 이상 부피의 lysozyme 단결정 시료를 성장시켰다. 자기장 영향 하에서 성장시킨 단결정은 자기장의 영향 없이 성장한 시료보다 평균 부피가 크고 결정도가 우수하였으며, X-선 측정 결과에서도 해상도가 높고 작은 mosaicity를 나타내었다.

1. 서

단백질과 같은 바이오물질의 결정구조분석은 신약개발 을 위한 복합화합물 설계를 위한 초기 정보수집 단계로, 완벽에 가까운 결정구조정보를 얻을수록 부작용이 거의 없는 신약을 설계할 수 있다[1]. 단백질 구조분석에는 $\mathrm{NMR}, \mathrm{X}$-선 및 중성자회절 등이 주로 이용되며, 이 중 $\mathrm{X}$-선 및 중성자회절을 이용한 결정구조분석은 원자단위 의 3 차원 구조분석이 가능하다. 국내 연구자들은 포항가 속기연구소의 단백질 빔라인과 고성능의 Lab X-ray 장

\footnotetext{
Corresponding author

Tel: +82-42-868-4401

Fax: +82-42-848-4629

E-mail: sakim@kaeri.re.kr
}

치를 이용하여 단백질 구조분석과 신약개발 등에 성과를 얻고 있다. 그러나 수소원자와 수화구조를 다량 포함하 고 있는 바이오물질의 특성 상 수소원자의 위치 정보를 정확히 얻어 낼 수 있는 중성자빔을 이용할 경우 신약개 발에 기여할 수 있는 단백질의 기능과 구조 규명에 필요 한 입체구조를 제공할 수 있다[2].

이와 같이 중성자회절은 바이오물질의 수화구조를 포 함한 3차원 상세구조 분석에 최적의 핵심기술이나, $\mathrm{X}$-선 에 비해 에너지가 상대적으로 낮기 때문에 구조분석에 충분한 데이터를 얻기 위해서는 평균 부피 $1 \mathrm{~mm}^{3}$ 이상 의 단백질 단결정이 필요하다. 물론 시료 내의 수소원자 를 중수소원자로 치환한 경우는 약 $~ 0.1 \sim 0.2 \mathrm{~mm}^{3}$ 정도 의 시료로도 측정이 가능하다[3]. 또한 일본의 J-PARC 과 미국과 유럽에 건설 중인 파쇄중성자원(spallation 
neutron source)을 사용하는 시설에 설치되었거나, 설치 예정인 중성자 바이오회절장치의 경우는 부피 $~ 0.1 \mathrm{~mm}^{3}$ 이하의 단결정 시료의 측정도 가능하다는 전망이다[4].

$\mathrm{X}$-선에 비해 중성자빔의 낮은 에너지를 극복하기 위한 방법으로 중성자 회절실험에 사용할 시료 단결정을 크게 성장시키기 위해, 자기장 영향 하에서 단결정을 성장시 킬 경우 크기와 결정도를 향상시킬 수 있다는 기존 연구 에 $[5,6]$ 착안하여 기존 연구자들이 단결정 성장에 활용 한 장치보다 월등히 간단하고 편리한 자기장 단결정 성 장장치를 개발하였다. 또한 이를 이용하여 hen egg-white lysozyme $(\mathrm{HEWL})$ 단결정을 자기장 영향 하에서 성장시 켰을 때 부피와 광학품질이 매우 향상된다는 것을 입증 하였다[7]. 이 논문에서는 자기장 단결정 성장장치의 개 발과 이 장치를 이용한 결과를 보고하고자 한다.

\section{2. 실험방법}

\section{1. 자기장 단결정 성장장치 개발}

사파이어 또는 초전도체 등의 무기물 단결정은 일반적 으로 시약 물질을 고온에서 용융시켜 성장시키는 초크랄 스키법[8]이나 존멜팅법[9]을 사용하는데 비해, 유기물인 단백질을 단결정으로 성장시키는 일반적인 방법은 산도 $(\mathrm{pH})$, 온도, 압력 등을 변화시켜 용액 내의 단백질 농도 를 과포화 상태로 만들어 단백질의 석출속도를 조절하여 결정화시키는 것이다. 결정화 과정에서 결정 성장의 촉 진제로 $\mathrm{MgCl}_{2}, \mathrm{NaCl}, \mathrm{NiCl}_{2}, \mathrm{MnCl}_{2}, \mathrm{CoCl}_{2}, \mathrm{FeCl}_{2}$, $\mathrm{FeCl}_{3}$ 과 같은 염화물을 첨가하는데, 이 중 $\mathrm{Ni}, \mathrm{Mn}, \mathrm{Co}$, $\mathrm{Fe}$ 등의 상자성 물질은 자기장 하에서 단백질 결정성장 에 영향을 주어 순수하고 거대한 결정성장을 가능하게 한다 $[10,11]$. 기존의 자기장 발생장치는 거대한 대형 전 자석을 이용하고, 자기장 균질도가 일정한 부분이 제한 적이기 때문에 수주에서 수개월이 소요되는 결정성장과 관련하여 여러 조건을 동시에 실험하기 매우 어려우며

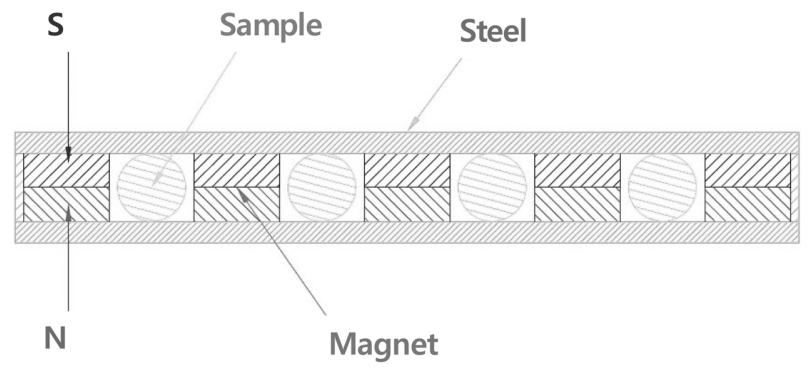

Fig. 1. Schematic illustration of the magnetic field device.

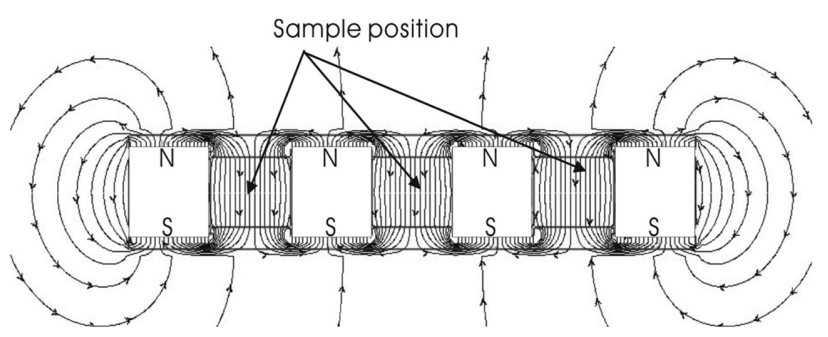

Fig. 2. Simulation of the magnetic field directions.

때론 필요한 조건을 구현할 수 없다.

자기장 하에서 단백질 단결정을 성장시키기 위해 시뮬 레이션 프로그램을 이용하여 일반적인 영구자석을 이용 한 장치를 구상하였다. 그 결과 쉽게 구할 수 있는 $\mathrm{Nd}$ 이 첨가된 표면자기장 약 $0.55 \mathrm{~T}$ 의 영구자석을 Fig. 1 과 같이 배치하여 시료 위치에서 약 $0.3 \mathrm{~T}$ 의 자기장을 얻도 록 하였다. 이와 같이 구성한 단결정 성장장치의 자기력 선 시뮬레이션 결과 $\pm 3 \%$ 이하의 균일한 자기장이 시 료 영역을 통과함을 확인하였다(Fig. 2). 또한 시작품을 만들어 Benchmarking Crystal 단결정을 성공적으로 성 장시켜 성능을 입증하였다. Fig. 3(a)는 단결정 성장장치 의 개념도이며 Fig. 3(b)는 제작 완료한 시작품이다. 이 장치는 추가적인 자석 배치를 통하여 시료 삽입 위치와 수를 조절하는 것은 물론 비커의 길이를 고려하여 자석 을 수직방향으로 추가 배치하는 것이 가능하므로 시료 용액이 담긴 비커 전 영역에 균일한 자기장 공급이 가능
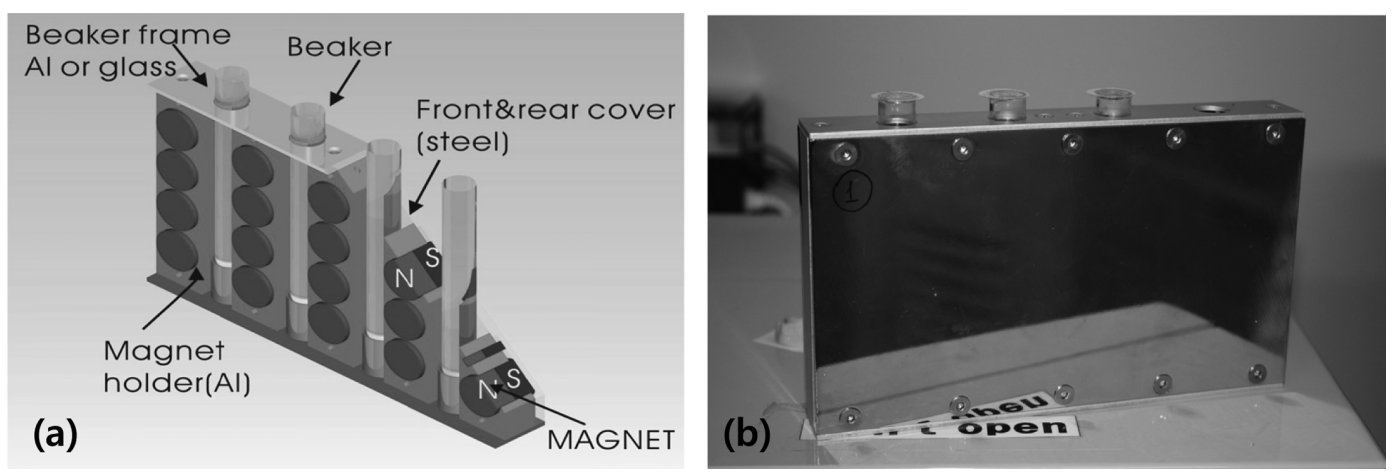

Fig. 3. Concept design (a) and a product (b) of the magnetic field device suitable for the test tubes. 
하다.

위의 단결정 성장장치는 에너지가 낮은 중성자회절용 거대 단결정 성장에 적합한 장치이다. $\mathrm{X}$-선 회절용 시료 는 높은 에너지의 Lab X-ray 장치 또는 방사광을 이용 하여 실험하기 때문에 수 마이크로미터 이내의 작은 단 결정도 구조분석이 가능하다. 이러한 단결정을 성장시키 기 위해 대부분의 대학 및 연구소에서 단백질 결정성장 에 이용하는 일반적인 crystal batch에 자기장을 가할 수 있는 단백질 단결정 성장장치를 설계하였다. 일반적으로 사용하는 crystal batch의 경우, 폭이 $60 \mathrm{~mm}$ 이상이므로 가할 수 있는 자기장이 낮게 된다. 목적하는 $0.3 \mathrm{~T}$ 확보 를 위해 영구자석 배치를 여러 형태로 하여 자기력선 시 뮬레이션을 수행하였다.

기존 단결정 성장장치의 시료위치와 좌우 자석의 상하
에 탄소강을 배치한 방법에 추가로 자석을 상하 위치에 자기장 방향을 평행하게 배치한 경우(Fig. 4(b)), 시료 위치에서의 자기력선의 분포가 기존 장치보다 약 $15 \%$ 감소하였다. 이와 반대로 추가 자석의 자기장 방향을 기 존 자석과 반대로 하면 시료 위치에서의 자기력선 분포 는 약 $15 \%$ 증가하는 한편, 외부로 발산하는 자기장을 Fig. 5(a)와 같이 시료 지역에 가두어 둘 수 있다. 이와 같은 방법은 시료 위치의 자기장을 약 $15 \%$ 향상시키는 효과와 함께 외부로 발산하는 자기장을 완전히 차단하는 효과가 있다. 자기회로 구성에 이용되는 탄소강판 상하 부분 전체에 영구자석을 설치하지 않고, 좌우 일부분에 자석을 배치하여도 동일한 자기장 증가 효과를 얻을 수 있으나, 이 경우 외부로 방출되는 자기장 차단은 어렵다 (Fig. 5(b)).

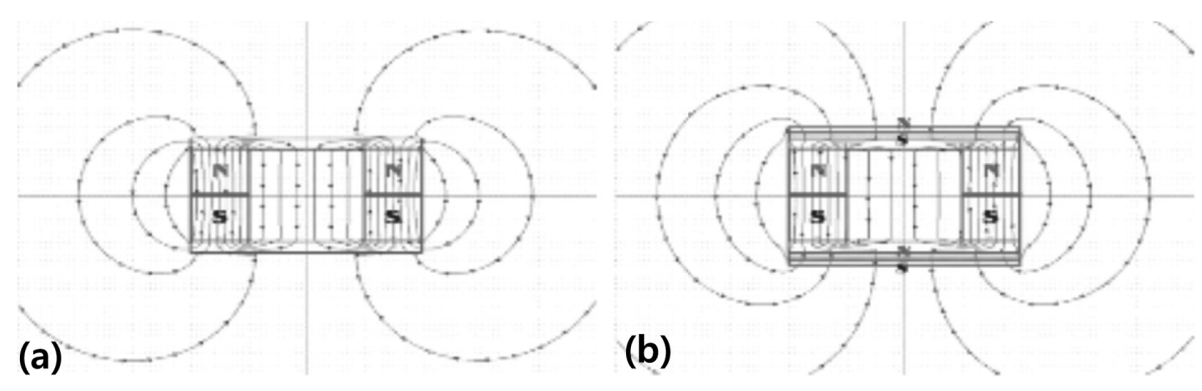

Fig. 4. The magnetic field directions of the first device (a) and additional magnets at the top and bottom parallel direction to the existing magnets (b).
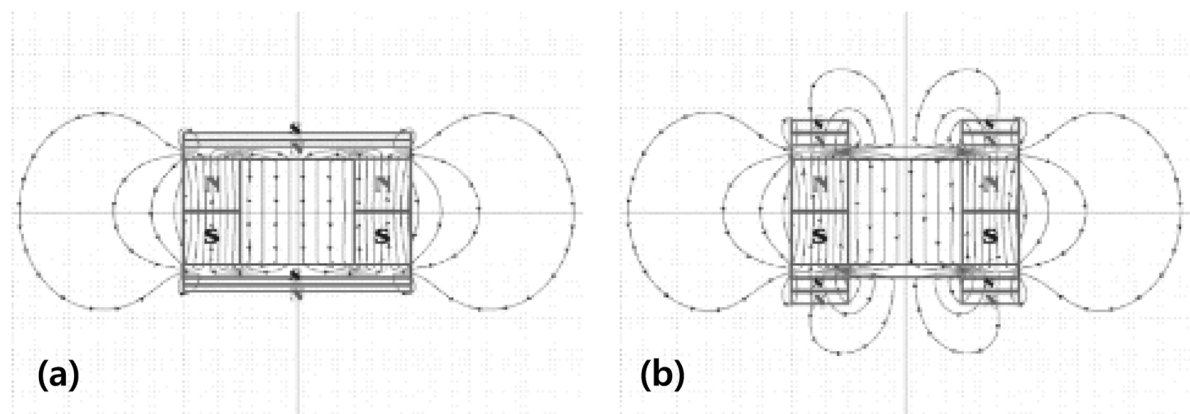

Fig. 5. The magnetic field directions of the additional magnets opposite direction to the existing magnets (a) and additional magnets at the top and bottom positions of the existing magnets (b).
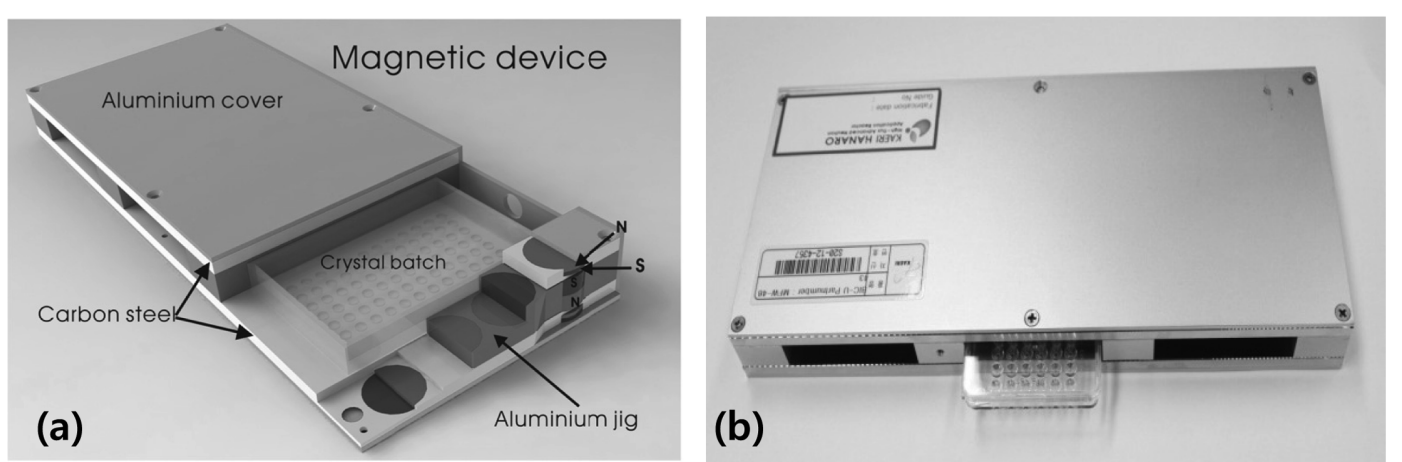

Fig. 6. Concept design (a) and a product (b) of the magnetic field device suitable for the commercial crystal-batch. 
Table 1

Experimental conditions and results of lysozyme crystal growth

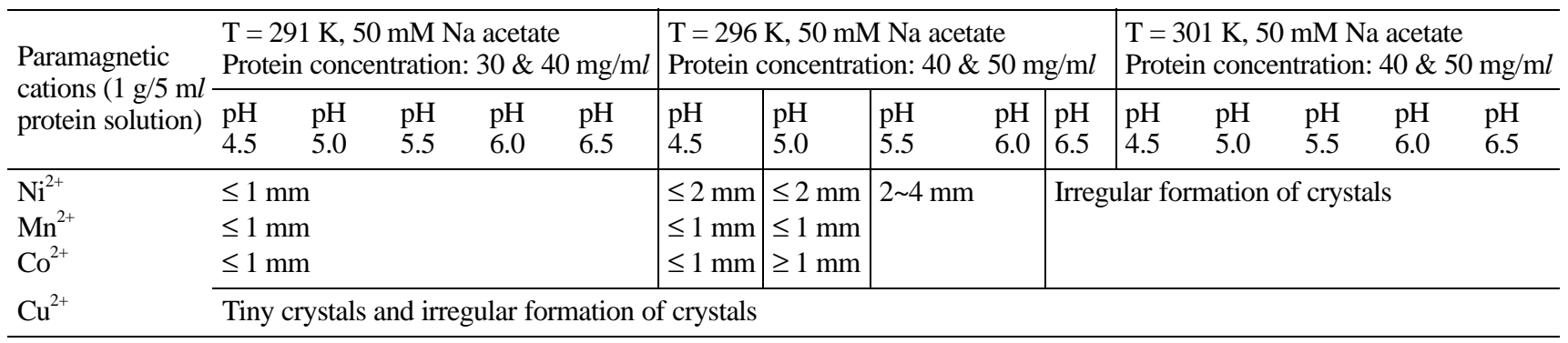

Crystals were analyzed in their early stages of growth (2 5 days from the setting of the experiment) and after they reached their maximum sizes (3 weeks).
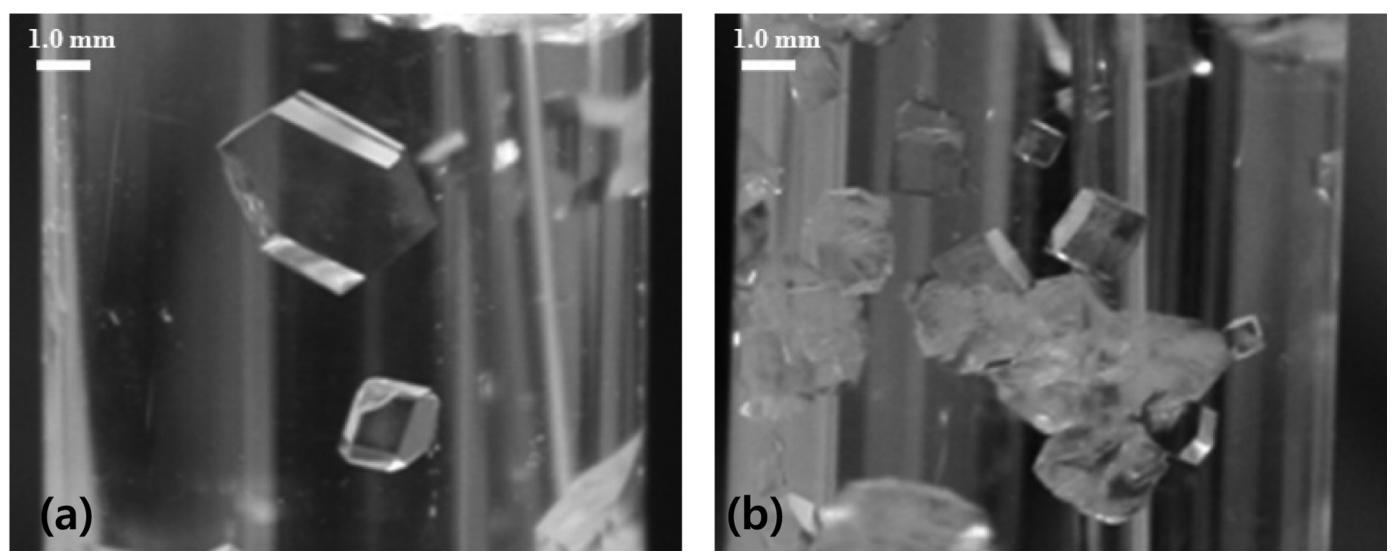

Fig. 7. The effect of the magnetic field on the quality of crystals. (a) Crystals have perfect transparency in the presence of a magnetic field $(0.3 \mathrm{~T})$. (b) Crystals have many micro-cracks in the absence of a magnetic field.

추가적인 자석 배치에 의해 얻어지는 $15 \%$ 이상의 자 기장 증폭은 비커에 비해 상대적으로 면적이 넓은 상용 crystal batch에 동일한 자기장 $(0.28 \mathrm{~T} \sim 0.3 \mathrm{~T})$ 의 공급이 가능 하다. 이를 적용한 고효율 자기장 단결정 성장장치의 시작 품을 제작하여(Fig. 6) HEWL 단결정 성장에 사용하였다.

\section{2. 단백질 단결정 성장실험}

$0.3 \mathrm{~T}$ 의 자기장을 가할 수 있는 단결정 성장장치는 인 큐베이터 안에 넣을 수 있으므로 다양한 온도 영향 하에 서 실험이 가능하다. 상자성 양이온을 포함한 염화물의 종류에 따라 온도, $\mathrm{pH}$ 그리고 단백질 농도를 달리하여 각각 자기장 영향의 유무 조건 하에서 $\mathrm{HEWL}$ 단결정을 성장시켰다. 이와 같은 다양한 조건 하에서의 단결정 성 장실험 결과를 Table 1 에 정리하였다. 표에서 보는 바와 같이 총 60 조건 중 $\mathrm{HEWL}$ 단결정이 가장 잘 성장한 조건은 다음과 같다.

- 단백질 농도: $50 \mathrm{mg} / \mathrm{ml}$

- 온도: $296 \mathrm{~K}$

- 자기장: $0.3 \mathrm{~T}$

- salt: $\mathrm{MnCl}_{2}$
- pH: 6.0

Fig. 7(a)에서 보는 바와 같이, $\mathrm{MnCl}_{2}$ 용액과 자기장 영향 하에서 성장한 단결정은 완전히 투명하여 좋은 결 정성을 보이며, 이렇게 성장한 단결정은 평균 $10 \mathrm{~mm}^{3}$ 정도의 부피를 보였다. 이는 중성자회절용 시료로 우리 가 기대하였던 약 $1 \sim 2 \mathrm{~mm}^{3}$ 부피의 단결정에 비해 획기 적으로 큰 시료이며, 무엇보다 결정 전체가 투명하여 완 벽에 가까운 좋은 결정성을 보이는 단결정으로 성장하였 다. 이에 비해 자기장 영향이 없는 조건에서 성장한 결 정은 Fig. 7(b)에서 보듯이 대부분이 내부에 미세한 깨 짐이 있는 불투명한 모습을 보인다.

이번 연구를 통해 확보한 중성자회절용 시료는 한국원 자력연구원의 연구용 원자로인 '하나로'에 설치되어 현재 시운전 중인 중성자 바이오회절장치 $(\mathrm{Bio}-\mathrm{C})$ 를 이용하여 중성자회절데이터를 획득하여 구조를 분석할 예정이다.

\section{3. 결과 및 고찰}

본 연구에서 개발한 자기장 단결정 성장장치의 가장 큰 장점은 크기가 작고 다루기 쉬워서 다양한 조건의 실 


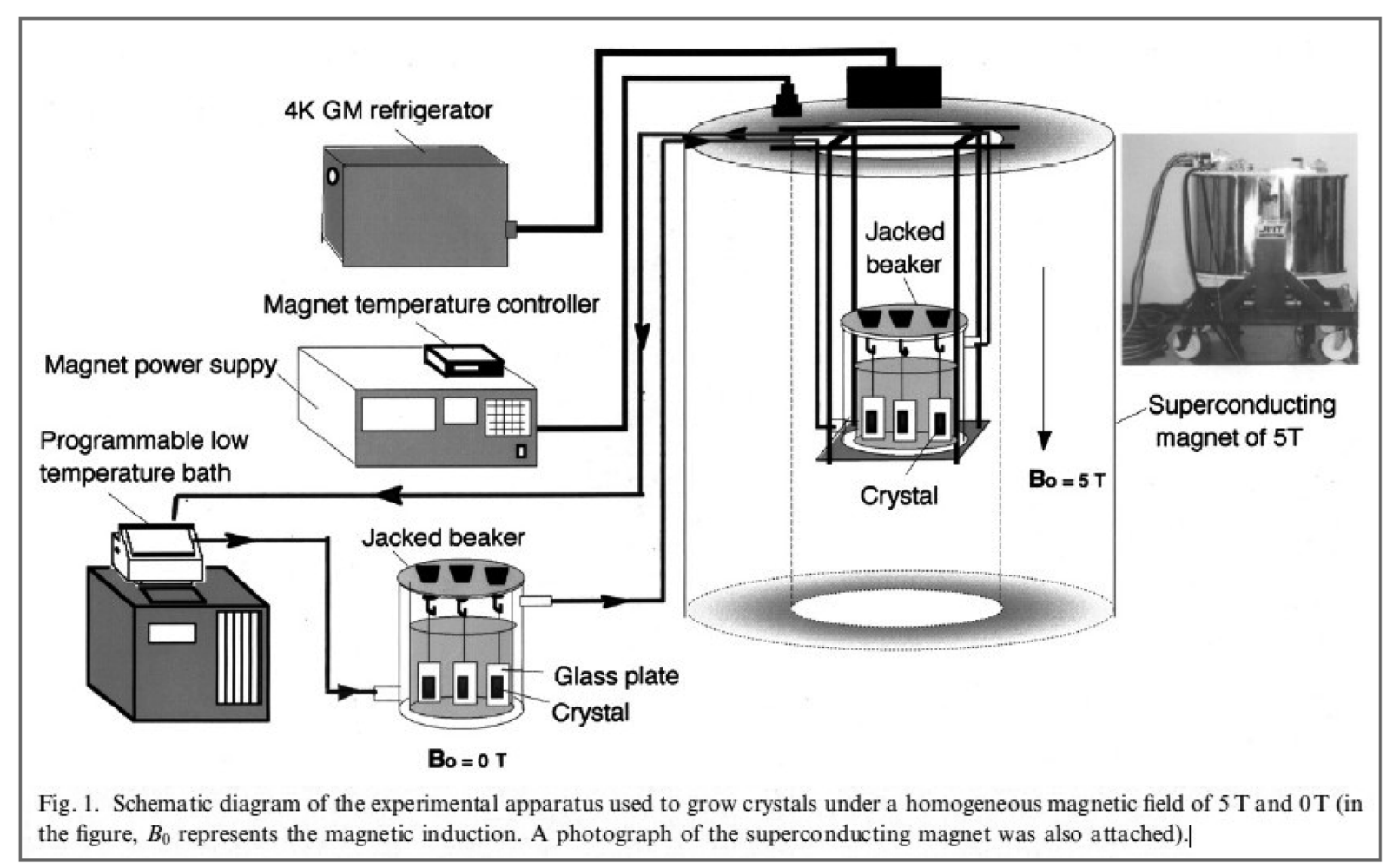

Fig. 8. Schematic diagram of the experimental apparatus using superconducting magnet by Guzman et al. [12].

험을 구현할 수 있다는 것이다. 또한 상용자석을 이용하 여 자기장을 인가할 수 있는 장치를 구성한 것은 비싸고 거대한 크기의 초전도자석을 이용하던 기존 방식을 획기 적으로 개선한 것이다.

Guzman 등은 Japan Magnet Technology Inc.의 초전 도자석 'JMTD-5T 300M'을 이용하여 L-alanine 단결정 을 성장시켰다[12]. 본 연구에서 개발한 자기장 단결정 성장장치와 비교를 위해 이들이 구성한 실험장비의 도식 도를 Fig. 8에 나타내었다. 그림에서 보듯이 이들은 직 경 $300 \mathrm{~mm}$ 의 내부에 seed crystal을 매단 비커를 위치 시키고 냉각기, 온도제어기 등을 설치하여 실험을 수행 하였다. 또한 Yin 등이 자기장 영향 하에서 Lysozyme 단결정을 성장시킬 때 사용한 장비도 Japan Magnet Technology Inc.의 초전도자석 'JMTD-10T 100M'와 JASTEC, Japan 사의 'JASTEC $16 \mathrm{~T}$ 50MF'이며, 이들 은 초전도자석과 함께 water bath를 포함하여 실험장비 를 구성하고 단결정을 성장시켰다 $[10,11]$. 이에 반해 본 연구에서 개발한 자기장 단결정 성장장치는 비커와 crystal batch를 이용할 수 있는 모델 모두 $27 \mathrm{~W} \times 15 \mathrm{H} \times$ $3 \mathrm{~T} \mathrm{~m} \mathrm{~m}^{3}$ 크기 또는 이보다 작은 크기로 제작 가능하여 일반적인 인큐베이터 안에 넣고 실험하는 것이 가능하다 (Fig. 9).

기존 연구자들이 초전도자석을 사용하여 5 10 T의 고 자기장 하에서 단결정을 성장시킨 것과 달리, 본 연구에 서는 상용자석을 사용한 단결정 성장장치로 $0.3 \mathrm{~T}$ 의 자

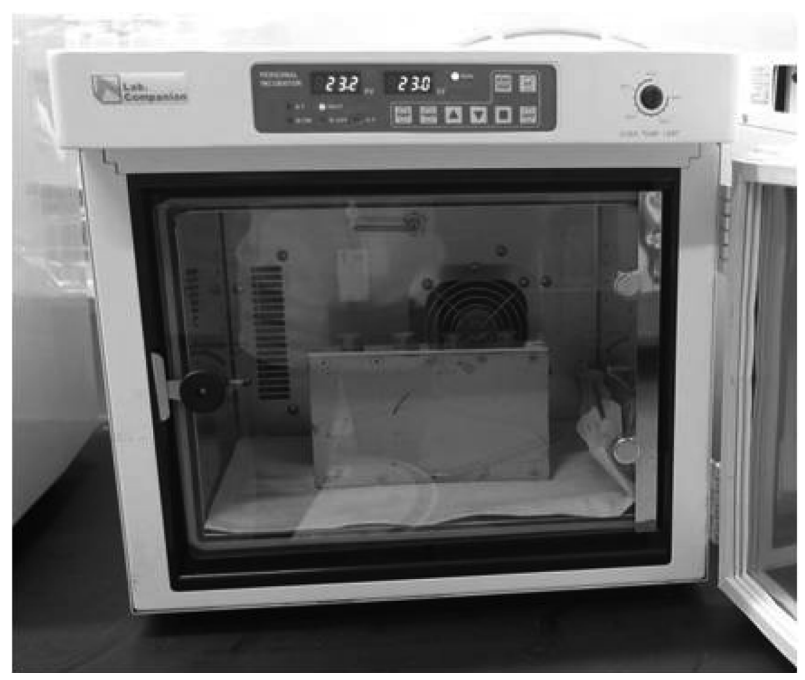

Fig. 9. The magnetic device with the tubes is placed into an incubator.

기장 영향 하에서도 내부의 깨짐이 거의 없는 투명하고 결정도가 좋은 부피 $10 \mathrm{~mm}^{3}$ 이상의 거대 단결정 성장이 가능하다는 것을 입증하였다.

Fig. 10은 단결정 성장장치를 이용하여 HEWL 단백질 단결정을 성장시킨 결과이다. 단결정 성장실험을 시작한 지 3 일째 되는 날 확인한 결과, 자기장의 영향이 없는 조건에서는 seed crystal이 거의 관찰되지 않았으나, 자 기장 하에서 결정을 성장시킨 조건에서는 $\mathrm{HEWL}$ 단결 

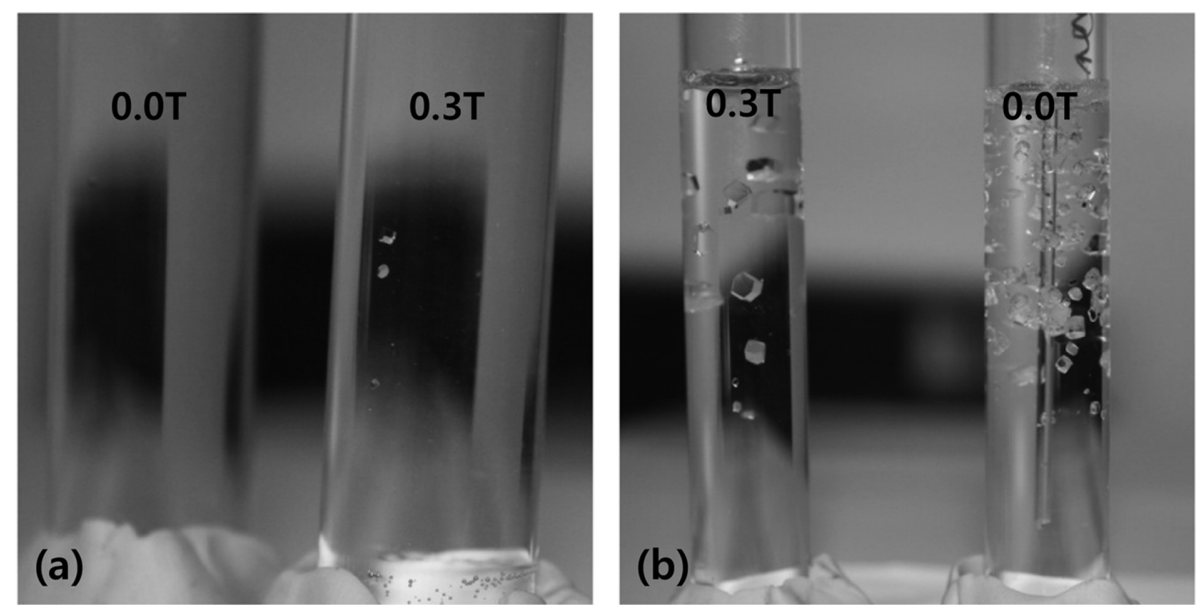

Fig. 10. Lysozyme crystal growth in the presence $(0.3 \mathrm{~T})$ and in the absence of a magnetic field. Photographs were taken 3 days after (a) and 14 days after (b) the start of the experiment.

정의 seed가 다수 관찰되었다(Fig. 10(a) 참조). 성장실 험을 시작한지 14 일째 되는 날 확인한 결과는, 자기장 영향 하에서는 상대적으로 적은 수의 단결정이 크고 좋 은 결정도를 보이며 성장한 반면, 자기장의 영향이 없는 조건에서는 많은 수의 결정이 생성되었으나 대부분 내부 의 깨짐이 있고 크기가 작은 결정들로 성장한 것을 관찰 할 수 있었다(Fig. 10(b) 참조). 이와 같이 자기장 영향 하에서 결정을 성장시킬 경우 seed가 상대적으로 빠르게 형성되며 일단 형성된 seed는 결정도가 좋은 거대결정으 로 성장하는 반면, 자기장의 영향 없이 결정성장을 시도 한 경우는 결정 seed의 형성이 느리게 진행되다가 급속 히 많은 crystallite가 동시에 형성되어 주위의 다른 결정 들과의 간섭에 의해 거대 단결정으로 성장하지 못하는 것은 물론, 이 과정에서 결정 내부에 미세한 깨짐이 발
생하게 되는 것을 알 수 있다.

단결정 성장에 미친 자기장의 영향을 확인하기 위해

Table 2

X-ray diffraction data analysis of HEWL

\begin{tabular}{lll}
\hline $\mathrm{MnCl}_{2}, \mathrm{H}_{2} \mathrm{O}$ & Magnetic field $0.0 \mathrm{~T}$ & Magnetic field $0.3 \mathrm{~T}$ \\
\hline lattice & Tetragonal & Tetragonal \\
space group & $\mathrm{P}_{3} 2_{1} 2$ & $\mathrm{P}_{3} 2{ }_{1} 2$ \\
$\mathrm{a}[\AA]$ & 79.67 & 79.43 \\
$\mathrm{~b}[\AA]$ & 79.67 & 79.43 \\
$\mathrm{c}[\AA]$ & 37.76 & 37.64 \\
$\alpha\left[^{\circ}\right]$ & 90 & 90 \\
$\beta\left[^{\circ}\right]$ & 90 & 90 \\
$\gamma\left[^{\mathrm{O}}\right]$ & 90 & 90 \\
Mosaicity & 0.300 & 0.111 \\
Resolution & 1.90 & 1.79 \\
\hline
\end{tabular}
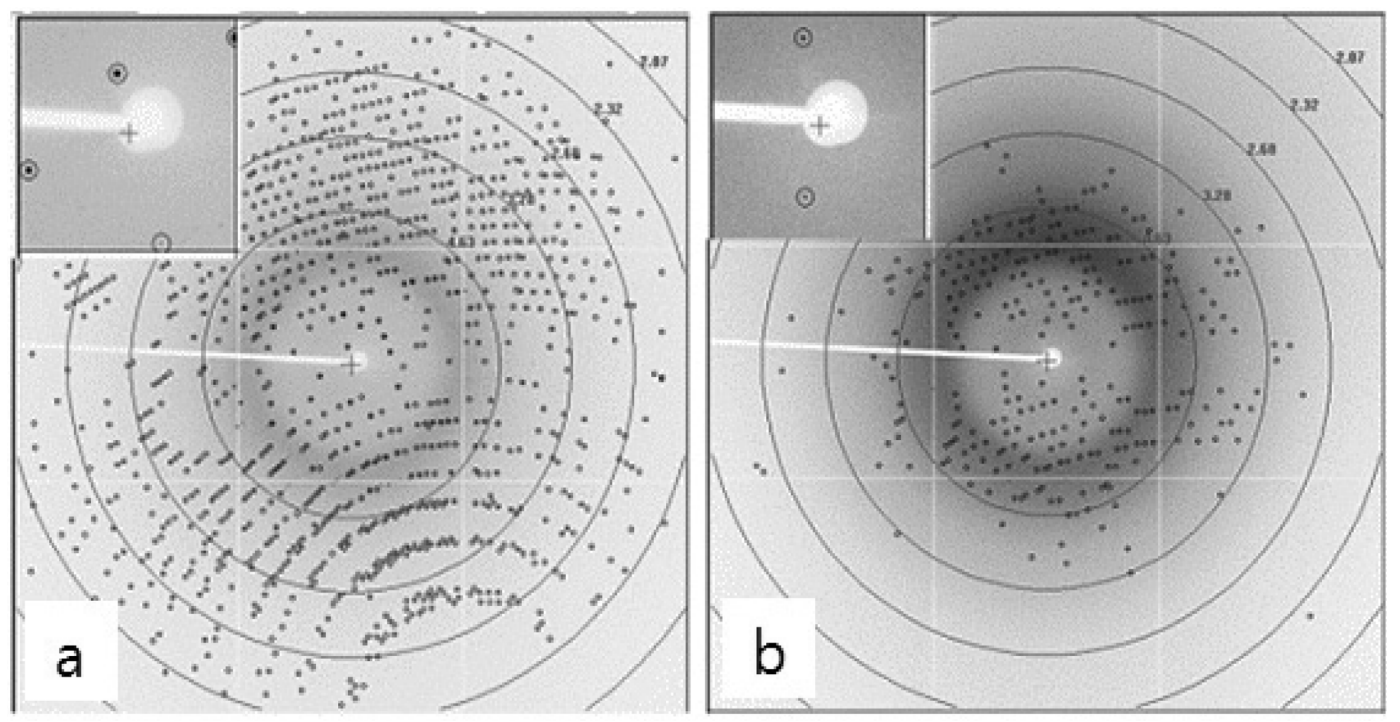

Fig. 11. X-ray diffraction data of HEWL measured by 7A beamline at PAL. (a) Diffraction pattern of the crystal grown with a magnetic field. (b) Diffraction pattern of the crystal grown without a magnetic field. 
다른 조건은 같고 자기장 영향이 없이 성장한 결정과 $0.3 \mathrm{~T}$ 의 자기장 하에서 성장시킨 결정에 대해 $\mathrm{X}$-선 회절 데이터를 측정하여 분석하였다. 측정에 사용한 단결정은 $25^{\circ} \mathrm{C}, \mathrm{pH} 6.0, \mathrm{MnCl}_{2}$ 용액에서 성장시켰으며, 포항가속 기연구소의 $7 \mathrm{~A}$ 빔라인에서 회절 데이터를 수집하였다. 방사광에 의한 손상을 최대한 줄이면서 모든 각에 대한 회절패턴을 얻기 위해 $1^{\circ}, 1.5^{\circ}$ 의 간격을 두고 0.02 초간 측정하였다. 회절 데이터를 'HKL2000'을 이용하여 분석 한 결과 결정구조는 동일하나 $0.3 \mathrm{~T}$ 자기장 영향 하에서 성장한 결정의 격자상수가 상대적으로 작게 나타났다. 단결정의 결정도를 확인할 수 있는 mosaicity는 자기장 영향 하에서 성장시킨 시료가 작게 나타났으며 해상도는 높게 나타났다(Table 2). 이 결과는 회절패턴에서도 확인 할 수 있는데, Fig. 11에서 보듯이 자기장 하에서 성장 시킨 단결정의 spot이 크기가 작고 선명하게 나타나 자 기장 영향 하에서 성장한 $\mathrm{HEWL}$ 단결정의 결정도가 더 우수함을 확인할 수 있다.

\section{4. 결 론}

본 연구에서 개발한 자기장 단결정 성장장치는 다양한 크기와 모양을 갖는 상용 crystal batch와 비커 등을 이 용하여 $0.3 \mathrm{~T}$ 정도의 자기장 영향 하에 단결정을 성장시 킬 수 있는 장치이다. 용도에 따라 다양한 크기와 모양 의 단결정 성장장치를 제작하는 것이 가능하며, 결정 성 장 실험실에서 일반적으로 사용하는 인큐베이터에 넣고 실험할 수 있으므로 온도를 변화시키며 다양한 실험 조 건을 구현하여 바이오단결정 성장의 최적 조건을 찾는데 활용할 수 있다. Lab X-ray와 방사광 실험에 적합한 크 기의 시료 성장은 물론, 중성자 회절실험에 필요한 평균 $1 \mathrm{~mm}^{3}$ 이상의 큰 단결정을 성장시키는 것도 가능하다. 무엇보다 이 장치를 이용하여 자기장 영향 하에서 결정 도가 향상된 단결정 시료를 얻을 수 있으므로 결정구조 분석에 응용이 가능할 것으로 판단된다.

\section{감사의 글}

이 연구는 기초기술연구회의 협동연구사업 융 - 복합 Seed형 과제(과제번호 Seed-11-7)와 한국원자력연구원의 자체연구사업의 지원을 받아 수행하였습니다.

\section{참 고 문 헌}

[1] Y. Liu, N.M. Luscombe, V. Alexandrov, P. Bertone, P. Harrison, Z. Zhang and M. Gerstein, "Structural genomics: a new era for pharmaceutical research", Genome Biology 3 (2002) 4004.1.

[2] N. Niimura, "The significance of the neutron structural biology in the post-genomic era", Physics \& High Technology 11(1/2) (2002) 14-17.

[ 3 ] M.P. Blakeley, P. Langan, N. Niimura and A. Podjarny, "Neutron crystallography: opportunities, challenges, and limitations", Curr. Opin. Struct. Biol. 18 (2008) 593.

[4] I. Tanaka, K. Kusaka, T. Hosoya, N. Niimura, T. Ohhara, K. Kurihara, T. Yamada, Y. Ohnishi, K. Tomoyori and T. Yokoyama, "Neutron structure analysis using the IBARAKI biological crystal diffractometer (iBIX) at J-PARC", Acta Cryst. D66 (2010) 1194.

[5] G. Sazaki, E. Yoshida, H. Komatsu, T. Nakada, S. Miyashita and K. Watanabe, "Effects of a magnetic field on the nucleation and growth of protein crystals", J. Crystal Growth 173 (1997) 231.

[6] P. Bénas, L. Legrand and M. Riès-Kautt, "Strong and specific effects of cations on lysozyme chloride solubility", Acta Cryst. D58 (2002) 1582.

[7] E. Magay, S. Cho and S. Kim., "Enhancing the volume and the optical quality of hen egg-white lysozyme crystals by coupling the salt concentration gradient crystallization method with a magnetic field", J. Appl. Cryst. 45 (2012) 1066.

[ 8 ] S.J. Lim, H.Y. Shin, J.H. Kim and J.I. Im, "Finite element analysis for czochralski growth process of sapphire single crystal", J. Korean Crystal Growth and Crystal Technology 21 (2011) 193.

[9] S.J. Kim and J.K. Park, "Crystal growth and transport current properties of cylindrical (YSmNd)-Ba-Cu-O superconductors by zone melt growth method", J. Korean Crystal Growth and Crystal Technology 21 (2011) 199.

[10] D.C. Yin, Y. Oda, N.I. Wakayama and M. Ataka, "New morphology, symmetry, orientation and perfection of lysozyme crystals grown in a magnetic field when paramagnetic salts $\left(\mathrm{NiCl}_{2}, \mathrm{CoCl}_{2}\right.$ and $\left.\mathrm{MnCl}_{2}\right)$ are used as crystallizing agents", J. Crystal Growth 252 (2003) 618.

[11] D.C. Yin, L.Q. Geng, Q.Q. Lu, H.M. Lu, P. Shang and N.I. Wakayama, "Multiple orientation responses of lysozyme crystals to magnetic field when paramagnetic salts are used as the crystallization agents", Crystal Growth \& Design 9 (2009) 5083.

[12] L.A. Guzman, K. Ogawa, E. Suzuki and K. Shimizu, "Effect of a magnetic field on the surface topography of L-alanine crystals", J. Crystal Growth 249 (2003) 335. 